\title{
DIFFERENCES IN THE METHANE CONTENTS IN THE COALBED METHANE ENRICHMENT REGION OF THE SOUTHERN QINSHUI BASIN, CHINA
}

\author{
HE, Y. L. ${ }^{*}$ - PENG, S. P. - DU, W. F. - ZoU, G. G. - SHI, S. Z. \\ State Key Laboratory of Coal Resources and Safety Mining, China University of Mining \& \\ Technology, Beijing 100083, China \\ *Corresponding author \\ e-mail: Yunlanhe@pku.edu.cn
}

(Received 24 $4^{\text {th }}$ Oct 2016; accepted $20^{\text {th }}$ Dec 2016)

\begin{abstract}
The enrichment irregularity of coalbed methane has been a problem for exploration and development. Great differences exist in methane enrichment even between different wells within a region. To study the main factors and reasons controlling these differences, we selected a relatively mature development block within a coalbed methane enrichment region of the Southern Qinshui Basin, China. Using individual well data, 3D seismic data, and methane content data and considering the coalbed methane (CBM) reservoir as a closed system, we analysed the enrichment irregularity of CBM in coalbed $3 \#$ and the various geologic factors influencing the enrichment.The results show that the CBM reservoir formation resulted from an interaction of various geologic factors, the evolution process is irreversible, and all of these factors are subject to certain internal relationships. The enrichment is controlled by several factors, such as tectonic development, formation pressure, coalbed structure, properties of roof strata, and hydrogeological conditions. Among these, formation pressure and coalbed structure are the most likely factors to cause differences in methane contents. Burial depth affects formation pressure, which consequently affects the saturation level of CBM in its adsorption state. Moreover, the coalbed structure determines the development of the reservoir space.Larger reservoir space and higher coalbed pressure are more favourable for CBM enrichment and the best enrichment region appears where both factors correlate well,this is particularly obvious in synclinal areas. Furthermore, tectonic development controls the overall form of CBM reservoirs, fault development reduces methane content and the mudstone cap provides a trap condition for CBM accumulation.
\end{abstract}

Keywords: coal; CBM; reservoir; sealing performance; geology; main factors

\section{Introduction}

Coalbed methane (CBM) is a natural gas that is generated during the process of coal rock thermal evolution.Methane gas is most predominant in coal rock thermal evolution; $80 \%$ of CBM exists in coal rocks in an adsorption state and forms an authigenic methane reservoir. Due to its unique occurrence and coalbed heterogeneity, CBM content still differs greatly, even within the same enrichment region. Previous studies have analysed the following factors influencing CBM enrichment: coalbed thickness (Chen and Song, 2007; Hemza et al., 2009; Hou et al., 2014), burial depth (Liu et al., 2010; Tan et al., 2013; Yang et al., 2013), coalbed structure (Gao et al., 2012; Moore, 2012), tectonic development (Groshon et al., 2009; Kędzior, 2009; Kong et al., 2011; Guo et al., 2014), roof stratum (Chen et al., 2006; Zhou et al., 2013; Song et al., 2013; Lin and Su, 2007), and hydrogeological conditions (Yao et al., 2014; Wang et al., 2007, 2011). However, due to the limitations presented by wellscarcity and the small number 
of control points, geological factors arereally too scattered and at too large of a scale for research;therefore they cannot satisfy the requirements for recognizing and analysing the changes in well-to-well methane content.

The Southern Qinshui Basin (Fig. 1) is an important CBM region that contains reserves up to $3.28 \times 10^{12} \mathrm{~m}^{3}$.It is considered the most valuable region for CBM exploration and development (Cai et al., 2011; Su et al., 2005). East block 1 of the Sihe Mine is a relatively mature block located within the CBM enrichment region. This block displays great differences in reservoir properties and rapid changes inmethane content, which decreases from $28.12 \mathrm{~m}^{3} / \mathrm{t}$ to $18.98 \mathrm{~m}^{3} / \mathrm{t}$ over the six CBM wells that are distributed in sequence within $1468 \mathrm{~m}$ ofthe coalbed $3 \#$. Therefore, in this paper we treated the CBM reservoir as a closed system. We aim to identify the main factors controlling the differences in CBM content by studying this block, andthen we explain the real reasons for CBM differences in the enrichment region. In addition, we explore the CBM enrichment mechanism and prediction method.

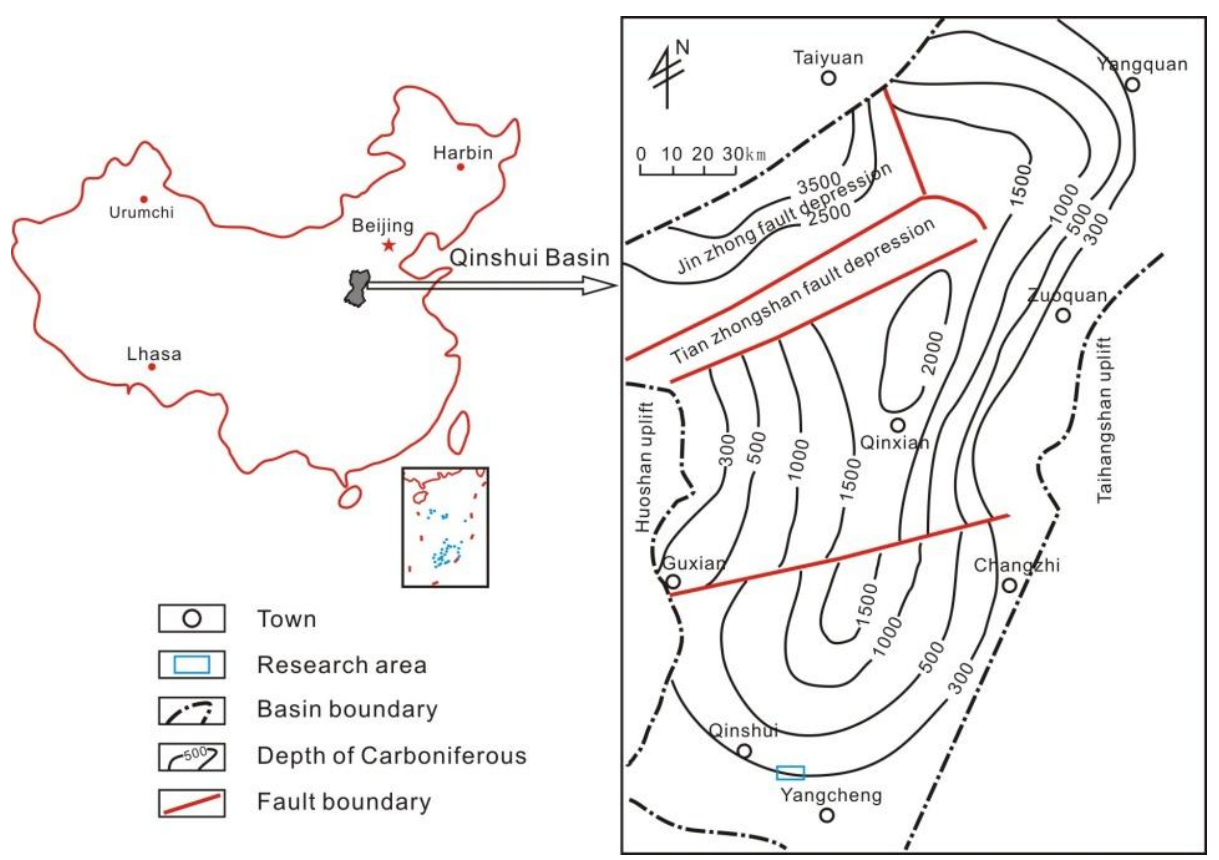

Figure 1. Location map of the Southern Qinshui Basin and depth contour map of the base of the Carboniferous

\section{Geological background}

\section{Regional structure}

As one of the Mesozoic Craton basins of northern China, the Qinshui Basin was formed in the late Paleozoic and was subsequently subjected to uplift and denudation due to crustal movement during the Triassic. The Yanshan movement during the Jurassic and Cretaceous separated the basin from the North China Craton to form a complex NNE-SSW synclinal basin (Su et al., 2005; Cai et al., 2011; Zou et al., 2013). Currently, 
the Qinshui Basin is surrounded by the uplifts of the Taihang, Zhongtiao, Wutai, and Huoshan Mountains. The research area is located in the southern part of the Qinshui Basin. The formation nearly tends northeast (NE) with a dip angle generally $<10^{\circ}$, and the structure is relatively simple with no large-scale faults. However, some NNE axial folds have developed in some areas.

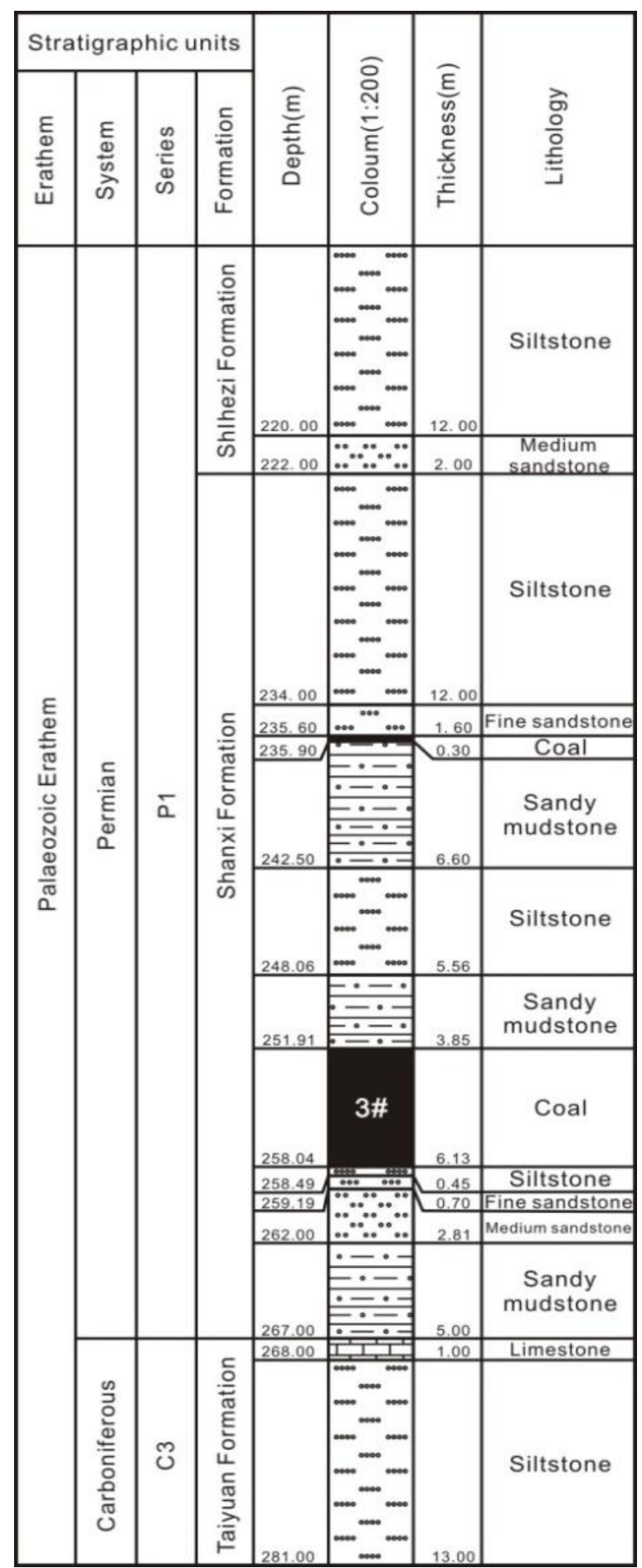

Figure 2. Stratigraphic column of the Permo-Carboniferous coal-bearing strata in the study area 


\section{Coal-bearing strata}

The research area mainly has two sets of coal-bearing strata, which are classified into a total of 15 coal-bearing layers: the Taiyuan Formation in the upper series of the Carboniferous system and the Shanxi Formation in the lower series of the Permian System. Therein, coalbed 3\# of Shanxi Formation and coalbed 15\# of Taiyuan Formation are minable coalbeds with a burial depth between 200 and 1000 meters giving priority to medium- and high-elevation metamorphic bituminous coal and anthracite. Coalbed 15\# is relatively thin at approximately 3 meters. Coalbed $3 \#$, located at the bottom of the Shanxi Formation, is distributed stably in a continuous manner and is the target stratum of this research (Fig. 2). Coalbed 3\# has a thickness between 4.46 and 6.79 meters, with an average of 5.94 meters, and there is a dirt band layerless than 0.3 meters thick, interbedded at the bottom. The surfacelithology is dominated by mudstone, sandy mudstone, and interbedded siltstone, and some of the roof strata contain coalbed, fine sandstone, and sandstone. The bottom lithology is dominated by mudstone and sandy mudstone and is accompanied by a sandstone series with interbedded coal and limestone.

\section{Methods}

To distinguish the heterogeneity of small-scale reservoirs and analyse the main factors and reasons controlling the differences in CBM content, the authors selected east block 1 in the Sihe Mine as the research area. It is $3.57 \mathrm{~km}$ long and $0.87 \mathrm{~km}$ wide and covers an area of approximately $3.10 \mathrm{~km}^{2}$. We collected borehole data from 51 wells within the work area e.g., drilling, logging, and fracturing data and 3D seismic data. In Table 1, we summarize various parameters of individual wells derived from borehole data, including the coalbed burial depth, coal occurrence elevation, coalbed thickness, and coalbed density, as well as the statistics of the mudstone thickness within $20 \mathrm{~m}$ of the roof and bottom layers. We also collected methane content data from 20 wells, which were derived from the results of drill coring measurements and direct analysis. Data marked with“*”" were obtained from reperforated test wells during the later period of development and are for reference only and not as the basis for analysing the methane accumulation mechanism.

To obtain better information regarding CBM reservoirs, we adopted a research method that combined geological research with geophysics. The geological research concentrated on sedimentary evolution, coal rock genesis, tectonic development, coal thickness, burial depth, coalbed structure, reservoir seal performance, hydrogeological conditions, and other geological factors influencing and controlling the CBM content. The geophysical methods used were conventional seismic interpretation and wave impedance inversion. The conventional seismic interpretation was aimed at the contours as well as fault identification. The wave impedance inversion focused on analysing the properties of the coalbed and roof. 
Table1. The individual wells data statistics

\begin{tabular}{|c|c|c|c|c|c|c|c|c|}
\hline Well & $\begin{array}{c}\text { Burial } \\
\operatorname{depth}(m)\end{array}$ & Elevation (m) & Thickness (m) & $\begin{array}{l}\text { Density } \\
\left(\mathrm{g} / \mathrm{cm}^{3}\right)\end{array}$ & $\begin{array}{l}\text { Mudstone } \\
\text { thickness of } \\
\text { roof stratum } \\
\text { of coal within } \\
20 \mathrm{~m}(\mathrm{~m})\end{array}$ & $\begin{array}{c}\text { Mudstone } \\
\text { thickness of } \\
\text { bottom stratum } \\
\text { of coal within } \\
20 \mathrm{~m}(\mathrm{~m})\end{array}$ & $\begin{array}{c}\text { Break-down } \\
\text { pressure (MPa) }\end{array}$ & $\begin{array}{c}\text { Methane } \\
\text { content }\left(\mathrm{m}^{3} / \mathrm{t}\right)\end{array}$ \\
\hline 2011zx-cc-01 & 206.38 & 349.12 & 6.22 & 1.46 & 16.15 & 15.75 & - & $11.57 *$ \\
\hline 2011zX-cc-02 & 322.94 & 337.86 & 5.93 & 1.46 & 17.74 & 17.65 & - & $8.47 *$ \\
\hline 2011zx-cc-03 & 329.12 & 339.84 & 5.54 & - & 16.20 & 16.30 & - & $9.55^{*}$ \\
\hline 2011zx-cc-04 & 328.72 & 339.31 & 5.58 & 1.49 & 17.15 & 15.27 & - & $11.43 *$ \\
\hline 2011zx-cc-05 & 381.07 & 323.66 & 5.76 & - & 9.72 & 6.81 & - & $9.53 *$ \\
\hline $2013 z x-f c-02$ & 375.23 & 318.64 & 5.81 & - & - & - & - & - \\
\hline $2013 z x-f c-03$ & 306.45 & - & 5.75 & - & - & - & - & - \\
\hline $2013 z x-f c-05$ & 338.41 & - & 5.99 & - & - & - & - & - \\
\hline $2013 z x-f c-06$ & 368.21 & - & 6.09 & - & - & - & - & - \\
\hline 2013zx-fc-07 & 346.59 & - & 5.90 & - & - & - & - & - \\
\hline $2013 z x-f c-08$ & 389.47 & 310.07 & 6.08 & - & - & - & - & - \\
\hline 2013zx-fc-09 & 364.02 & 317.44 & 6.30 & - & - & - & - & - \\
\hline SH-053 & 209.08 & 342.80 & 6.25 & - & - & - & - & 24.36 \\
\hline SH-055 & 294.95 & 331.69 & 6.10 & 1.46 & 12.25 & 15.05 & & 18.98 \\
\hline SH-056 & 305.58 & 329.48 & 5.90 & 1.42 & 8.58 & 15.45 & & 21.27 \\
\hline SH-057 & 333.95 & 313.39 & 5.80 & - & - & - & - & 22.65 \\
\hline SH-058 & 339.27 & 316.28 & 5.90 & 1.41 & - & - & 11.70 & 24.89 \\
\hline SH-059 & 374.98 & 318.15 & 5.60 & 1.36 & - & - & 8.50 & - \\
\hline SH-060 & 367.8 & 316.94 & 6.00 & 1.39 & - & - & 8.10 & 28.12 \\
\hline SH-061 & 319.85 & 316.31 & 6.08 & 1.41 & - & - & 10.60 & 21.83 \\
\hline SH-063 & 243.15 & 332.60 & 6.38 & 1.41 & - & - & 12.20 & 28.69 \\
\hline SH-064 & 220.35 & 344.29 & 6.13 & 1.43 & - & - & 21.60 & - \\
\hline SH-065 & 223.81 & 339.06 & 6.12 & 1.48 & 15.30 & 15.30 & 12.30 & - \\
\hline SH-066 & 262.74 & 323.10 & 6.66 & 1.50 & 17.55 & 16.61 & 5.70 & - \\
\hline
\end{tabular}




\begin{tabular}{|c|c|c|c|c|c|c|c|c|}
\hline SH-067 & 312.73 & 332.79 & 5.84 & 1.46 & 18.40 & 16.05 & 8.50 & - \\
\hline SH-068 & 330.8 & 336.72 & 5.68 & 1.44 & 17.88 & 16.57 & 10.90 & - \\
\hline SH-069 & 343.65 & 326.37 & 5.80 & 1.55 & 14.00 & 16.40 & 10.70 & - \\
\hline SH-070 & 357.89 & 322.35 & 5.74 & 1.44 & 20.00 & 16.45 & 16.80 & - \\
\hline SH-071 & 364.4 & 317.06 & 6.40 & 1.44 & 12.10 & 16.00 & 16.10 & 24.93 \\
\hline SH-072 & 317.62 & 329.19 & 5.93 & 1.43 & - & - & 10.70 & - \\
\hline SH-075 & 250.73 & 319.61 & 6.17 & 1.40 & 15.75 & 15.55 & 8.00 & 27.47 \\
\hline SH-076 & 338.51 & 335.57 & 6.03 & 1.57 & 14.80 & 16.35 & 15.00 & 20.84 \\
\hline SH-077 & 359.19 & 288.15 & 5.81 & 1.43 & 12.89 & 17.10 & 14.80 & 24.71 \\
\hline SH-078 & 372.9 & 317.36 & 5.28 & 1.51 & 16.65 & 16.10 & 13.10 & 22.00 \\
\hline SH-079 & 389.86 & 308.94 & 5.90 & 1.45 & 17.55 & 15.77 & - & 24.83 \\
\hline SH-155 & 337.99 & 355.65 & 6.00 & 1.48 & 8.50 & 12.92 & 15.06 & - \\
\hline SH-248 & 345.01 & - & 6.15 & - & 7.21 & 13.25 & - & - \\
\hline SH-260 & 308.82 & 364.06 & 6.43 & 1.42 & - & - & - & - \\
\hline SH-298 & 259.47 & 345.79 & 4.46 & - & 15.55 & 17.60 & - & - \\
\hline SHJM-12 & 261.07 & - & 6.67 & - & 11.40 & 10.30 & - & - \\
\hline SHJM-13 & 278.01 & 321.87 & 5.82 & - & 10.66 & 10.04 & - & - \\
\hline SHJM-21 & 250.22 & 328.77 & 6.37 & - & - & - & - & - \\
\hline SHZK-07 & 317.80 & - & 6.32 & - & 6.60 & 10.22 & - & - \\
\hline SHZK-08 & 270.21 & - & 6.32 & - & 12.01 & 10.19 & - & - \\
\hline SHZK-09 & 297.12 & 332.52 & 5.71 & - & 15.60 & 10.55 & - & - \\
\hline 6-3 & 335.38 & 332.65 & 5.76 & - & - & - & - & - \\
\hline $6-5$ & 345.46 & 348.18 & 5.91 & - & - & - & - & - \\
\hline $7-2$ & 227.55 & 342.59 & 6.30 & - & - & - & - & - \\
\hline 311 & 373.05 & 319.23 & 6.16 & - & - & - & - & - \\
\hline $7-3$ & 272.12 & 333.40 & 5.33 & - & - & - & - & - \\
\hline $7-4$ & 321.39 & 326.19 & 5.82 & - & - & - & - & - \\
\hline
\end{tabular}




\section{Results}

\section{Coalbed structure feature}

The structure feature of the coalbed is relatively simple.Its top elevation is between $288.15 \mathrm{~m}$ and $355.65 \mathrm{~m}$, but the maximum fall is only $67.50 \mathrm{~m}$ (Fig. 3). The coalbed features slight undulations, including one anticline and three synclines, and its dip angles are relatively small at the fold flanks. Fault development is consistent with regional characteristics; there is no large fault, some small faults occur mainly in the core of the anticline and most faults developed in the NNE direction.

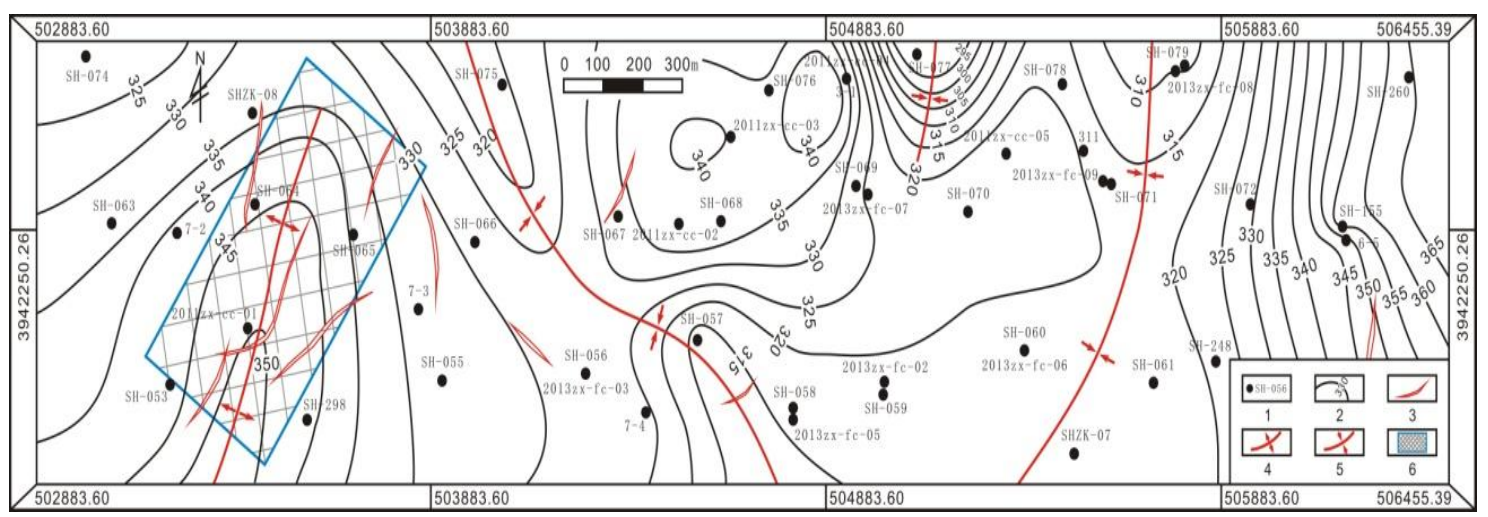

Figure 3.The structural map in the study area

1. CBM Well, 2. Elevationcontour of of roof stratum of coal, 3. Fault, 4. Anticline, 5. Syncline, 6.

The fault concentrated development zone

\section{Coalbed thickness and burial depth}

Coalbed thickness is the basis of methane enrichment; therefore, a thicker coalbed will theoretically produce a greater amount of total methane and a larger reservoir space during its evolution. Here, the coalbed sedimentary thickness is relatively constant. It ranges between 4.46 and $6.79 \mathrm{~m}$, with an average of $5.94 \mathrm{~m}$ (Fig. 4). The thinnest coalbed is near wellblock SH-298 at the core of the anticline and has a comparatively small range. The thicker sedimentary coalbeds developed mostly near synclines and the thickest (>6.7 meters) developed near wellblock SH-66.

The current coalbed burial depthsvary greatly; the shallowest region is in the western anticline, and the deepest region is in the eastern syncline (Figs. 3 and 5). The maximum difference between the shallowest and the deepest is approximately $200 \mathrm{~m}$, and the current overall difference may be significantly related to the tectonic evolution. The overlying strata are thicker at the synclines; these thicker rock formations are preserved because of weaker denudation in the later period. 


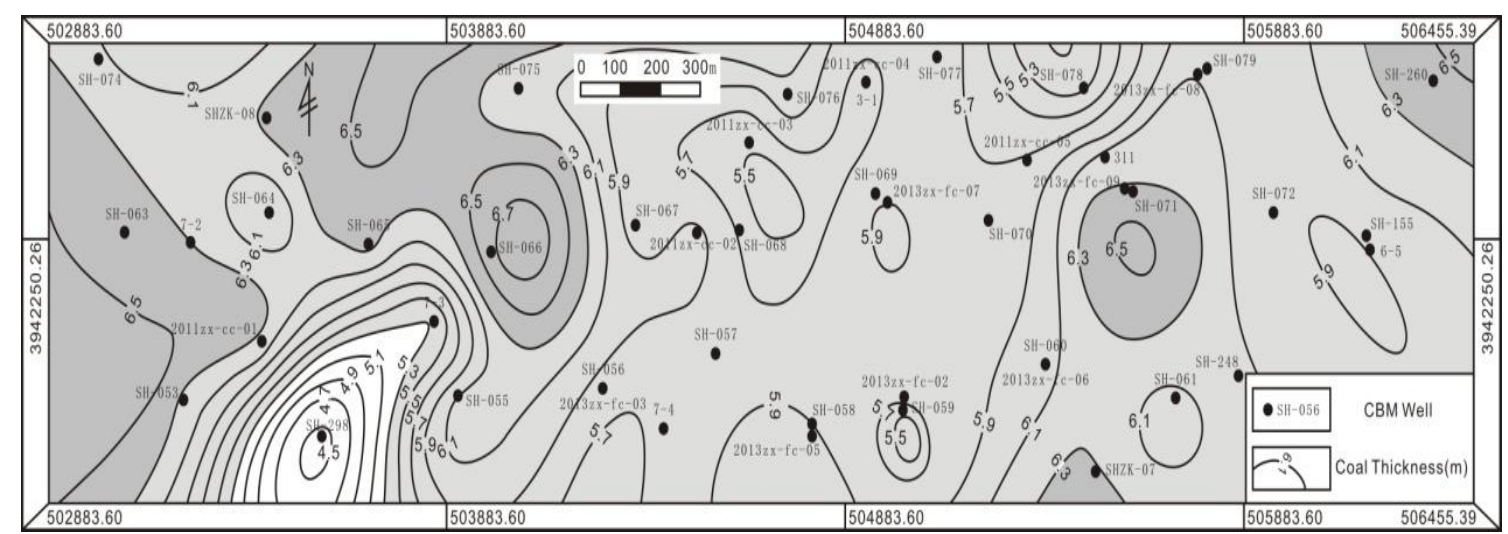

Figure 4. The contour map of coal thickness in the study area

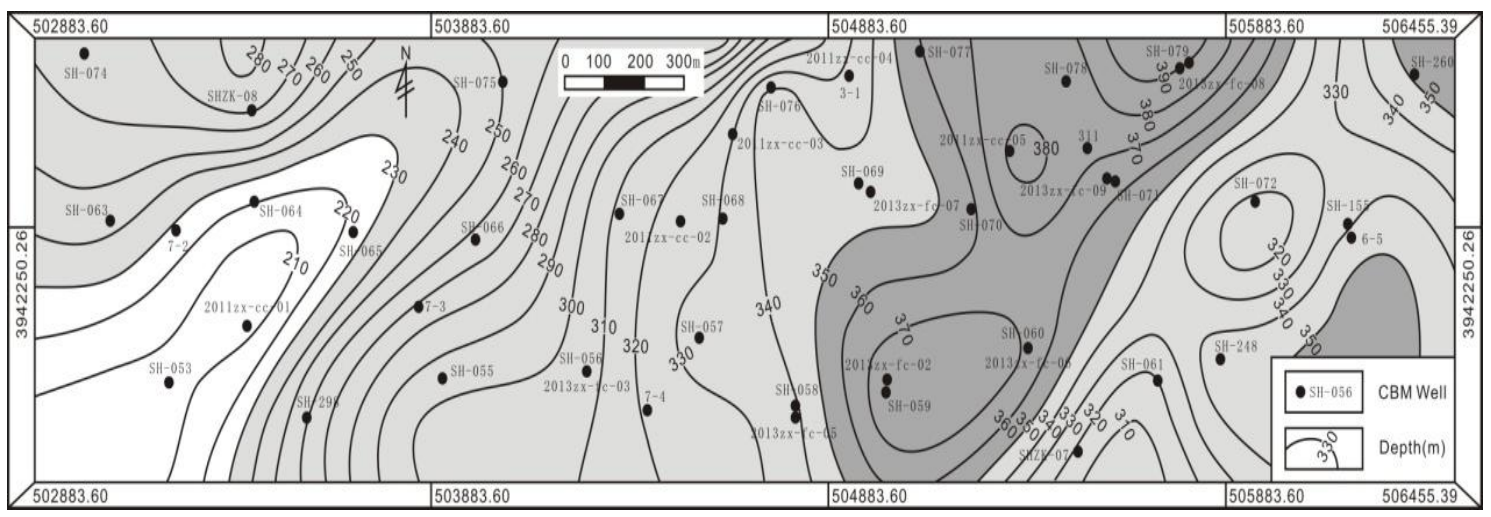

Figure 5. The contour map of coal burial depth in the study area

\section{Coalbed structure}

The coalbed structure refers to the structure of the coal rock itself, including the coal rock cracks, cleats, and matrix pores. Coalbed methane occurs mainly on the surface of the reservoir spaces in the coal rocks in an adsorption state. Theoretically, if the fractures, cleats, and matrix pores are better developed, the coal rock specific surface area and reservoir space will be larger and more conducive to CBM adsorption and accumulation.

No matter what factors cause the differences in the current coalbed structure, it isultimately characterized bythe different densities and reservoir space in the coal rock. This is preferably consistent with the density of the coal rock; a larger reservoir space results in a lowercoal rock density, and conversely, the coal rock itself is further densified. In the research area, the coalbed density is relatively small andthe maximum density difference between the lowest and highest density values is only $0.21 \mathrm{~g} / \mathrm{cm}^{3}$. The coalbed density distribution displayed several zones as detailed in Fig. 6, namely three relatively low-value zones with densities less than $1.40 \mathrm{~g} / \mathrm{cm}^{3}$, four relatively high-value zones withmore than $1.50 \mathrm{~g} / \mathrm{cm}^{3}$ and several other zones with densities between 1.40 and $1.50 \mathrm{~g} / \mathrm{cm}^{3}$. 


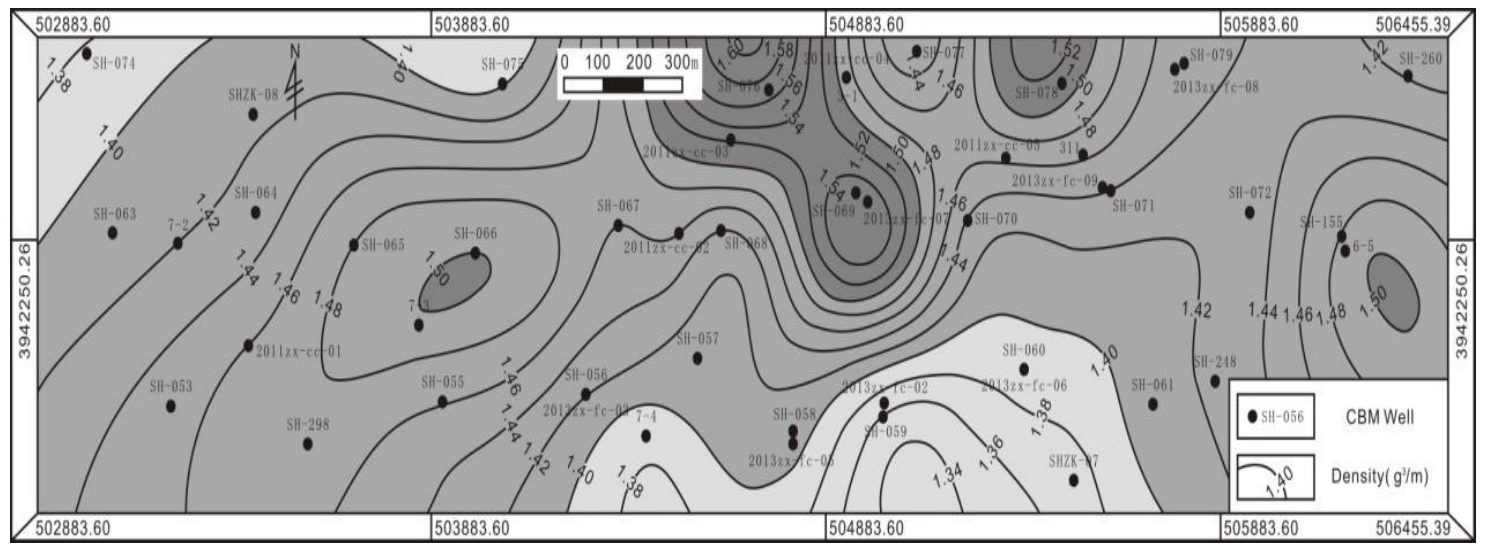

Figure 6. The contour map of coal density in the study area

Toobtain more detailed information on the coalbed structure and distinguish the horizontal differences, the 3D seismic data were inverted, and the wave impedance was analysed. When an elastic wave spreads through strata, denser rock results in a higher wave velocity and a smaller transit time interval. Wave impedance inversion carried out according to the wave velocity and density can, to some extent, reflect the density of the rock, i.e., the relative size of the reservoir space. Fig. 7 shows the inversion results of the wave impedance for coalbed 3\#; there are three obvious green zones developed with low-value wave impedance and a purple zone, which is near wellblock SH-055, with a concentrated high wave impedance. The difference in wave impedances represents the relative change in the coalbed density and thereby reflects the relative differences in the reservoir space.

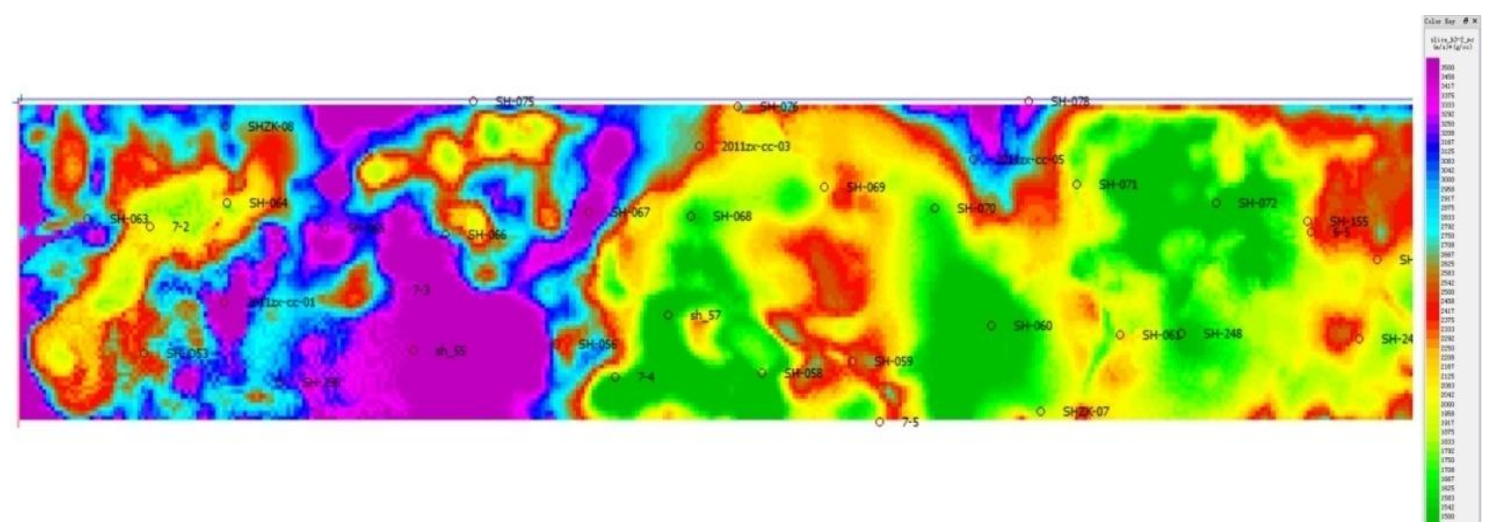

Figure 7.The impedance inversion map of $3 \#$ coal seam

\section{Coalbed top nature}

The lithology of the coalbed 3\# top predominantly consists of mudstone and sandy mudstone interlayered with fine and medium-sized sandstone. The single-well lithology data from the statistics of 27 wells show that the mudstone thickness is between 6.60 and $20.00 \mathrm{~m}$ (average: $14 \mathrm{~m}$ ), within $20 \mathrm{~m}$ of the coalbed top. The mudstone thickness, 
as a cap rock layer, provides good conditions for CBM accumulation and storage over the whole region. However, structural influences can cause this mudstone stratum to form fracture channels, such as fault cutting and folds. Considering this problem, the results of wave impedance inversion were used to analyse the density of the coalbed top (see Fig. 8). These wave impedance values are high overall but are slightly low around the anticline.The top cover, as the capping layer of the CBM reservoir, shows good sealing performance as a whole.

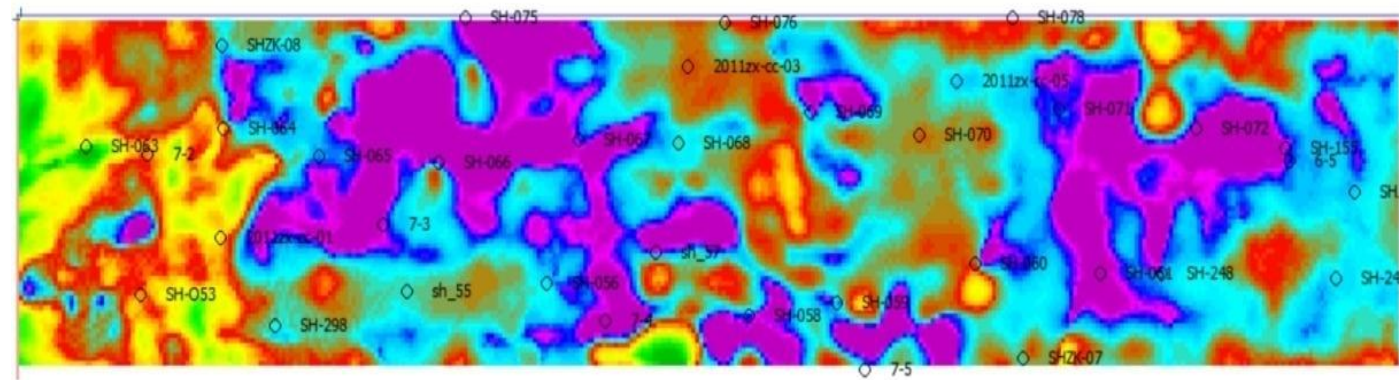

Figure 8. The impedance inversion map of roof stratum of 3\# coal

\section{Hydrogeological conditions}

Hydrogeological conditions are important factorsthat affect CBM enrichment; their analysis in this paper is based on previous research results and judgments made according to the actual situation in the research area (Ye et al., 2001, 2002; Su et al., 2005; Cai et al., 2011). Our research area is smalland located within the groundwater retention zone of the Southern Qinshui Basin. The formation water has a certain pressure-bearing capacity, additionally featureshave weak interchangeability and liquidity with the ambient environment and are supplied from outcrops in the east and south. Coalbed $3 \#$ has similar hydrogeological characteristics to those of coalbed 5\#; both have water-resisting layers that developed at their top and bottom, and some fault development has resulted in the formation of simple aquifers in these layers. The pressure-bearing formation water provides favourable conditions for preserving CBM in an adsorption state.

\section{Regularity of methane enrichment}

The regularity of methane enrichment in the research area was analysed using the data collected for air content. The area is approximately $3.10 \mathrm{~km}^{2}$ and it features a high rate of overall methane enrichment, as shown in Fig. 9. Supplementary drilling during the later period of development determined the minimum methane content to be approximately $19 \mathrm{~m}^{3} / \mathrm{t}$ and the maximum methane content to be approximately $29 \mathrm{~m}^{3} / \mathrm{t}$ (Table 1). For such a small block, the difference in methane content can be almost 
$10 \mathrm{~m}^{3} / \mathrm{t}$. Among the six wells, from well SH-60 westward to well SH-55, the measured methane content decreases progressively. In addition, there are three zones with methane contents higher than $27 \mathrm{~m}^{3} / \mathrm{t}$; they are located in wellblocks SH-59 to SH-60 and around wellblocks SH-63 and SH-75. The lower methane enrichment zones developed mainly in the area south of well SH-55, which is in the southeast of the research area. This difference in the CBM content is the important basis of the research in this paper.

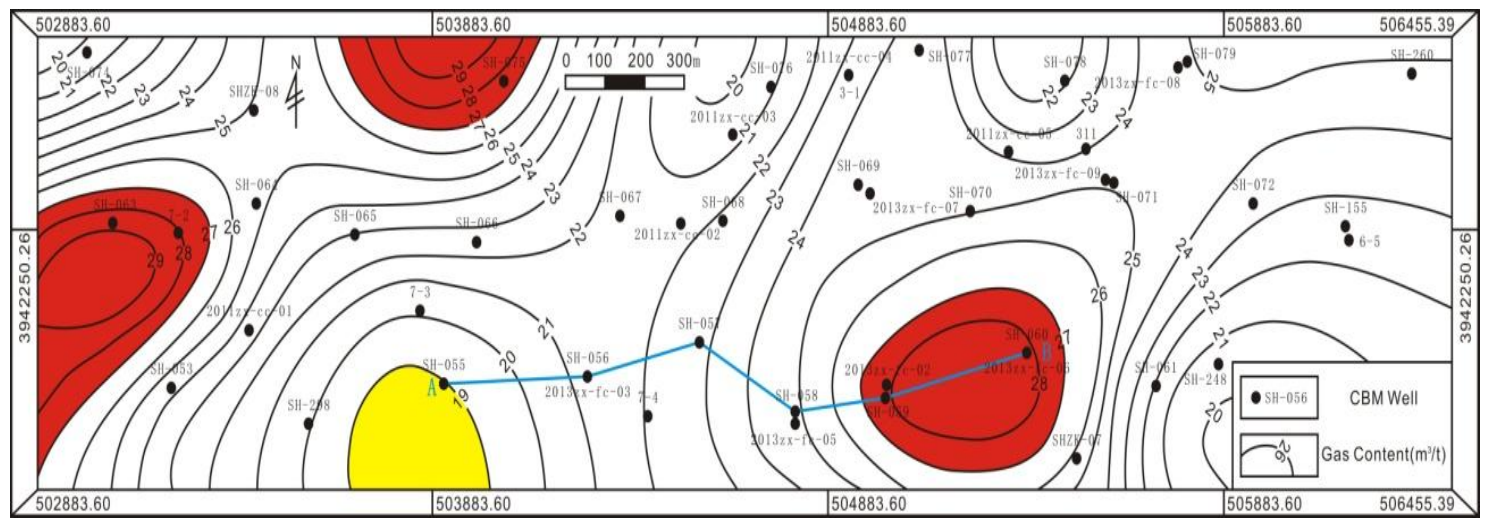

Figure 9. The contour map of methane content in the study area (not considering the influence of fault tomethane content)

\section{Discussion and conclusions}

\section{Discussion}

The research area is comparatively small, so geological conditions are similar to some extent. Coal rank has a certain influence on CBM content, and coal rock vitrinite, which hasa reflectivity value between 1.2 and 2.5, is considered to be the most favourable for generating gas (Creedy, 1988; Flores, 1998). Coalbed $3 \#$ has a maximum burial depth ofover $4000 \mathrm{~m}$ and was not subjected to magmatism or hydrothermal activity;yet, ithas the same burial evolution and coal rank characteristics (Cai et al., 2011). The original sedimentation environmentscould be different; for example, if tall vegetation was distributed near the water edge with an adequate nutrient supply and stunted vegetation wasfound relatively far from water, this could result ina difference in coalbed sedimentation (Moore et al., 2000; Moore, 2012; Shen et al., 2016). The coalbed rock composition (e.g. vitrinite, inertinite, minerals, ash, volatile matter), affects the CBM content and coal rock permeability (Butland and Moore, 2008; Cai et al., 2011), but it is considered to have little impact on methane enrichment as the research area is comparatively small, resulting in identical coal ranks and similar composition of target strata.

\section{Reservoir properties}

CBM content differences are based on differences in the reservoir properties, mainly tectonic development as well as coalbed thickness, burial depth, and structure. 
Tectonic development impacts CBM enrichment in two ways: as faults and folds. Previous research showed that methane enrichment in synclines is better than that in anticlines because in synclines, no faults developed, the overlying strata were thick enough, and there were no active hydrodynamics (Wang et al., 2006; Zou et al., 2013; Li et al., 2014). A hypertonic area with developed fractures is considered to be favourable for CBM enrichment (Gao et al., 2012; Moore, 2012) and strata that are structurally identical but lithologically dissimilar will respond differently during the development of such fractures (Qin et al., 2008, 2012). The faults and collapse columns have an obvious impact on CBM enrichment and may easily form effusive channels, inhibiting CBM accumulation. Compressive faults show relatively good sealing performance, which is favourable for CBM storage (Groshon et al., 2009; Kong et al., 2011; Guo et al., 2014).

There is one anticline and three synclines in the research area (Fig. 3). Figure shows the intersection of the coalbed top elevation and methane enrichment data; it indicates that the enrichment tends to decrease to a certain extent with an increase in coalbed elevation (Fig.10A). The three areas with relatively higher methane enrichment occurred near the synclines (Figs. 3 and 9). Fault development occurs on small scale in this area, and the faults tend to be normal and concentrated in the anticline cores. Near the faults, there are fewer wells, and therefore, we have fewer enrichment data; however, well 2011zx-cc-01 can be used as a good example. Compared with other confirmative wells drilled later, this well is located near a fault and far away from the surrounding developed wells. From the perspective of the gas supply radius, this well should have a greater advantage in terms of potential methane enrichment.However, compared with supplementary holes in the same batch, the methane content of $2011 \mathrm{zx}-\mathrm{cc}-01$ is the same as that in the other wells (Table 1). This phenomenon is likely to be caused by the fault that cuts through coalbed $3 \#$ and its top cover, enabling some CBM to diffuse through the fault grooves during the process of accumulation.

Coalbed thickness itself is not a precondition for high or low methane enrichment, and coalbeds more than one meter thick can become high-quality CBM reservoirs. The coalbed thickness first affects the total amount of hydrocarbon generation and the reservoir space. It also reflects the original sedimentary environment, and areascovered by thicker coalbeds will have relatively tall and lush vegetation. Previous analysis of coalbed thickness and CBM content shows that a thicker coalbed displays a higher methane content(Fang et al., 2003; Chen and Song, 2007). Fig. 10B shows the intersection of the coalbed thickness and methane enrichment; it also displays a certain regularity, but it is not applicable here. Comparison of the regularity of methane enrichment and the coalbed thickness distribution is shown in Figs. 3-4, where it can be seen that coalbed thickness is not the most direct cause of high or low methane enrichment in this area.

Coalbed burial depth involves various problems. On the one hand, the differences in burial depths are controlled by tectonic deformation and weathering denudation, and the burial depth in synclines is generally greater than that in anticlines. On the other hand, differences in burial depth can result in differences in the formation pressure, thereby 
influencing methane enrichment to a certain extent (Liu,2008;Peng et al., 2014; Tan et al., 2013). CBM, as an authigenic methane reservoir, generates natural gas that directly accumulates in the coal rock via adsorption and is not subjected to secondary migration. CBM enrichment and accumulation need a certain formation pressure, which constantly acts on the whole process, from hydrocarbon generation to CBM accumulation and storage (Li et al., 2003; Liu et al., 2010; Song et al., 2013; Yang et al., 2013).

The process of thermal evolution and hydrocarbonylation of the coalbed is irreversible and CBM build-up and storage is a process of continuous accumulation in situ. The CBM reservoir that we have considered in this research has gone through multiple stages of evolution, but this research will not focus on the evolution process. The current formation pressure has finally been fixed and has a more significant impact on CBM accumulation under an adsorption state. The previous research shows that a better positive correlation exists between coalbed burial depth and methane enrichment, with CBM content increasing with an increase in burial depth (Fig. 10C). However, burial depth is also related to formation pressure to some extent, with a greater burial depth leading to higher formation pressure. This provides the basis for a better positive correlation between fracture pressure and burial depth (Fig. 10D). The three data points in the top left corner of Fig. 10D indicate wells SH-63, SH-64, and SH-6; these are near the anticline core. The fracture pressures for these wells are in the order SH-63 $<\mathrm{SH}-65$ $<$ SH-64. The fracture pressure of the formation increases the closer it is to the anticline core, which agrees with the law stating that stress is concentrated in the cores of anticlines. Other data points are located near synclines and show that a more obvious positive correlation exists between formation pressure and burial depth. From the above analysis, we can conclude that greater burial depth, not locations in anticline cores, correlates with greater formation pressure and thus is more favourable to CBM enrichment.

The impact of coalbed structure on methane enrichment involves the reservoir space. Cleats, fractures, and matrix pores form the coalbed reservoir space and their degree of development determines the accumulative capacity of the coalbed (Palmer and Mansoori,1998;Palmer et al.,2007). On the one hand, the size of the reservoir space is characterized by the density of the coalbed; more developed cleats, fractures, and matrix pores lead to a lower density coal rock, which is more conducive to CBM enrichment. Fig. 10E shows the relationship between coalbed density and methane enrichment in this area. This scatter diagram reflects a certain degree of correlation, but it is not a perfect linear relationship because there are few single wells providing both density and methane enrichment data simultaneously. Comparing the regularity of methane enrichment and the distribution of coalbed density, we find that the latter strongly controls methane enrichment and the areas high in methane enrichment have all developed around areas with low densities (Figs. 6 and 9). Moreover, according to the wave impedance inversion results, coalbed density is comparatively low in those areas with lower relative wave impedance and such areas have relatively higher CBM contents, as seen in wellblocks SH-060 and SH-075. This also illustrates the role of coalbed structure on the difference in methane enrichment. 

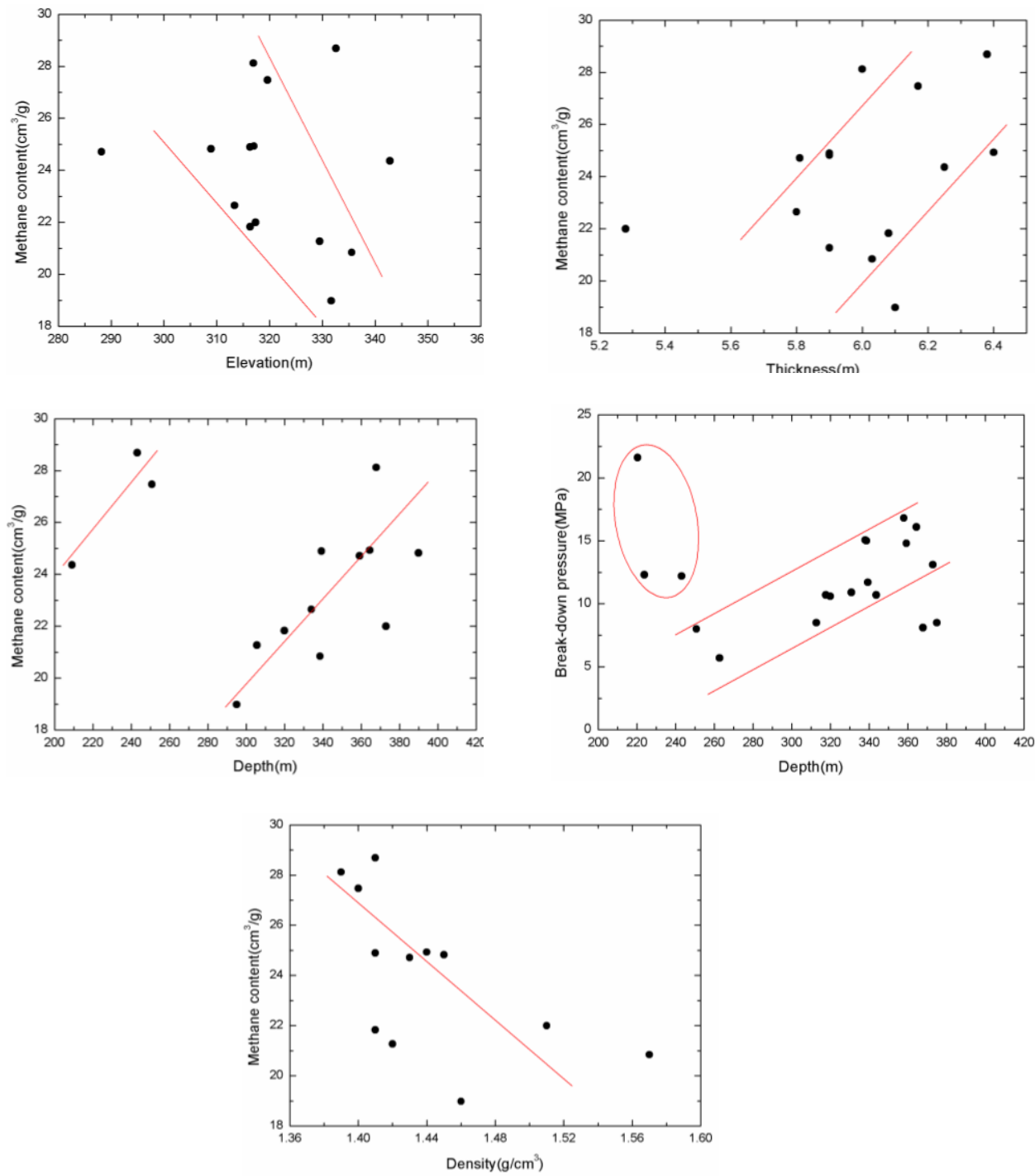

Figure 10. The scatter diagrams between methane content and effect factors

\section{Sealing performance of gas reservoir}

The sealing conditions and performance also affect CBM enrichment; they include top cover properties and hydrogeological conditions.

From sedimentation to completion of the diagenesis and during the evolution process from lignite to anthracite, each ton of coal can generate $268-393 \mathrm{~m}^{3}$ of gas (Zhang and $\mathrm{Li}, 1988$ ); however,only a small amount of CBM is ultimately preserved. The coalbed top is in direct contact with the coalbed and has experienced the same diagenetic evolution; therefore, the top density directly influences the residual CBM content ( $\mathrm{Li}$ et al., 2011; Kong et al., 2011; Liu, 2013; Liu et al., 2012; Zhou, 2013). Coalbed 3\# top is dominated by mudstone; single-well lithology data indicate that the average total thickness of the mudstone is $14 \mathrm{~m}$ within $20 \mathrm{~m}$ from the top and that the bottom mudstone is thicker (Table 1). The wave impedance inversion results showed that the 
coalbed top generally shows high wave impedance values, while relatively low values appear only around the anticline, which is again favourable for CBM accumulation and conservation.

Hydrogeological conditions can promote CBM accumulation and destroy CBM conservation. In $\mathrm{CBM}$ reservoirs, the water, $\mathrm{CBM}$, and coal rock have contact relationships as follows: $\mathrm{CBM}$ is adsorbed onto the surface of the coal rock pores while still in direct contact with the water. If the formation water is in a liquid state, it will migrate, and carry CBM with it.Therefore, it will reduce methane enrichment. If the formation water or other media do not migrate, it is very difficult for CBM in the adsorption state to migrate, adjust, and again accumulate in the same coalbed. In the research area, the formation water remained; the current formation water is weak in terms of interchangeability and liquidity and shows certain artesian performance, which is favourable for CBM accumulation. Moreover, the formation water is always in the state of retention as a fluid, so it has no direct impact on the difference in the horizontal CBM content.

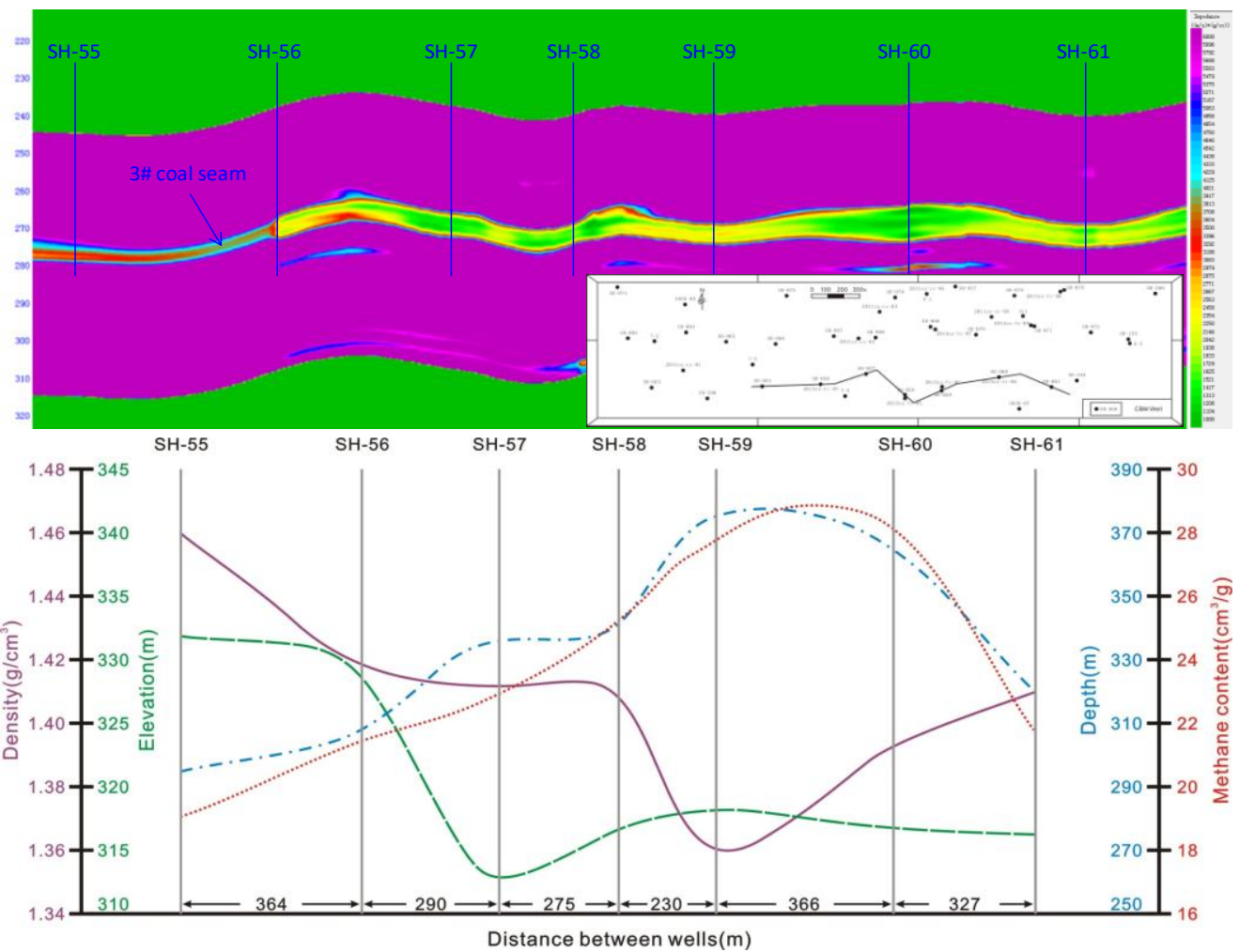

Figure 11. The section correlogram between $\mathrm{SH}-55$ and $\mathrm{SH}-61$

\section{Analysis of differences}

The tectonic development in the research area controls the coalbed movement and fault development and also simultaneously affects burial depth. The synclinal areas are more advantageous for CBM enrichment and better than the anticline on the whole. Burial depth and gas content are well correlated and the coalbed methane enrichment 
tends to rise with an increase in burial depth. Larger burial depths result in greater formation pressure, which is particularly obvious in synclinal areas. The formation pressure in the anticline area appears more complex, but shows, weak regularity due to conditions such as crustal stress, faults, and fractures. If the coal reservoir space is not taken into consideration, the difference in coalbed pressure could be the direct reason for the difference in CBM content. Nevertheless, the coalbed structure plays a strong role in controlling the gas content, and areas with high gas content are also areas of low density. Based on the above analysis and discussion, the most basic reason for the difference in CBM content over the research area is the difference in the coalbed structure and formation pressure, as CBM is most abundantly generated in areas where low density and high formation pressure are well correlated, for example, from wellblocks SH-59 to SH-60 (Fig. 11).

\section{Conclusions}

Using individual well data, 3D seismic data, and methane content data and considering the CBM reservoir as a closed system, we analysed the enrichment irregularity of $\mathrm{CBM}$ in coalbed $3 \#$ and the various geologic factors influencing the enrichment in research area. To obtain better information regarding CBM reservoirs, we adopted a research method that combined geological research with geophysics.

The results show that the research area for this study covers $3.10 \mathrm{~km}^{2}$. Coalbed $3 \#$ generally showed higher methane enrichment, but the CBM content still differed greatly between wells. The main factors influencing these differences include coalbed tectonic development, formation pressure, and coalbed structure.

Additionally, the coalbed structure and formation pressure are the most direct causes of the difference in CBM content; the coalbed structure determines the size of the reservoir space and the formation pressure determines the reservoir saturation of the adsorptive CBM. A degree of matching between the two is the decisive factor for the difference in CBM content. Areas relatively high in CBM content are located where the reservoir space is larger,the pressure is higher and fault development is insufficient, and this is particularly obvious in the synclines.

Finally, high-precision 3D seismic data can be adopted to obtain the coalbed tectonic development, movement, burial depth, structural attributes, top sealing performance, and other relevant information needed for the prediction of high CBM enrichment regions.

The CBM content differed greatly not only in the different areas but also in the adjacent wells within a region.It brings more difficulties to the CBM development and well deployment. This paper analysed the enrichment irregularity of CBM and the main geologic factors. The study results provide a theoretical basis for the CBM development and well deployment on the smaller scale area.And the study on the enrichment irregularity of CBM will be more refined in the future. 
Acknowledgements. The project was financially supported by Certificate of China Postdoctoral Science Foundation (2016M591286), National Natural Science Foundation of China (41602168) and Project of China Geological Survey (12120115102101).

\section{REFERENCES}

[1] Butland, C. I., Moore, T.(2008): A. Secondary biogenic coal seam gas reservoirs in New Zealand: A preliminary assessment of gas contents. - International Journal of Coal Geology 76(1-2):151-165.

[2] Cai, Y. D., Liu, D. M., Yao, Y. B., Li, J. Q., Qiu, Y. K.(2011): Geological controls on prediction of coalbed methane of No. 3 coal seam in Southern Qinshui Basin, North China. - International Journal of Coal Geology 88:101-112.

[3] Chen, T. J., Cui, R. F., Liu, E. R., Lang, Y. Q. (2006): Prediction of coal seam methane enriched areas using seismic data. - Journal of China University of Mining \& Technology(English Edition) 16(4):421-424.

[4] Chen, Z. H., Song, Y. (2007): Formation processes and advantageous models for High-Low-Rank coalbed methane reservoirs. - Xinjiang Petroleum Geology 28(3):275-278.

[5] Creedy, D. P. (1988): Geological controls on the formation and distribution of gas in British coal measure strata. - International Journal of Coal Geology 10(1):1-31.

[6] Fang, A. M., Hou, Q. L., Lei, J. J., Li, J. L., Yang, L. W., Hu, A. M. (2003): Effects of coalification on the formation and accumulation of coal-bed methane: a studying case from qinshui basin. - Geological Journal of China Universities 9(3):378-384.

[7] Flores, R. M. (1998): Coalbed methane: from hazard to resource. - International Journal of Coal Geology 35(1-4):3-26.

[8] Gao, L. J., Tang, D. Z., Xu, H., Meng, S. Z., Zhang, W. Z., Meng, Y. J., Wang, J. J. (2012): Geologically controlling factors on coal bed methane (CBM) productivity in Liulin. Journal of Coal Science and Engineering (China) 18(4): 362-367.

[9] Groshong, J., Richard, H., Pashin, J. C., McIntyre, J. C.(2009): Structural controls on fractured coal reservoirs in the southern Appalachian Black Warrior foreland basin. Journal of Structural Geology. 31: 874-886.

[10] Guo, B. K., Cheng, Y. P., Jin, K., Liu, Y. P. (2014): The impact of faults on the occurrence of coal bed methane in Renlou coal mine, Huaibei coalfield, China. - Journal of Natural Gas Science and Engineering 17:151-158.

[11] Hemza, P., Sivek, M., Jirásek, J. (2009): Factors influencing the methane content of coal beds of the Czech part of the Upper Silesian Coal Basin, Czech Republic. - International Journal of Coal Geology 79:29-39.

[12] Hou, H. H., Shao, L. Y., Tang, Y., Wang, S. A., Wang, X. T., Liu,S. (2014): Study on coal bed methane genetic types and formation models of low rank coal in China. - China Mining Magazine, 23(7):66-69.

[13] Kędzior, S. (2009): Accumulation of coal-bed methane in the south-west part of the Upper Silesian Coal Basin (southern Poland). - International Journal of Coal Geology80(1):20-34. 
[14] Kong X. W., Zhao Q. B., Sun F. J., Li G. Z., Ma C. L. (2011): New advances of productive \&enriching patterns and production characteristics of coalbed methane in china. - Natural Gas Geoscience 22(4):738-746.

[15] Li, Y., Tang, D. Z., Xu, H., Meng, S. Z., Lin, Y. N., Zhang, W. Z., Chen,Y. (2014): Characteristics of structural controlled coalbed methane in east margin of ordos basin. Coal Science and Technology, 42(6):113-117.

[16] Li, W. Z., Chen, G., Sun, B., Sun, F. J., Zhao, Q. B. (2011): Geological controls of coalbed methane enrichment in Daning-jixian area, Southeastern Ordos Basin. - Natural Gas Geoscience 22(2):352-360.

[17] Li, W. Z., Wang, Y. B., Cui, S. H., Xian, B. A., Chen, C. H., Wang, X. H. (2003): Analysis of the generation conditions of coalbed gas reservoir, Southern Qinshui Basin. - Coal Geology \& Exploration 31(2):23-26.

[18] Lin, X. Y., Su, X. B. (2007): Reservoiring mechanism of coalbed methan in Southern Qinshui Basin. - Natural Gas Industry27(7):8-11.

[19] Liu, D. G., Luo, X. J., Wan, M., Gong, H. Y. (2010): The coal-bed mathane accumulation factors and explorative target in Eastern Junggar Basin. - Xinjiang Petroleum Geology31(4):349-351.

[20] Liu, Q. X. (2008): An analysis on CBM hosting features and contributing factors in Pingdingshan Mining Area. - Coal Geology of China 20(3):31-34.

[21] Liu, Y. H., Li, M. X., Yang, X., Liu, C. C., Yan, L. (2012): Laws of coalbed methane enrichment and high prodectivity in the Fanzhuang Block of the Qinshui Basin and development practices. - Natural Gas Industry 32(4):29-32.

[22] Liu, Z. L. (2013): Fractal theory and application in city size distribution. - Information Technology Journals 12(17): 4158-4162.

[23] Moore, T. A. (2012): Coalbed methane: A review. - International Journal of Coal Geology 101:36-81.

[24] Moore T. A., Esterle, J.S., Shearer, J.C. (2000): The role and development of texture in coal beds: examples from Indonesia and New Zealand. -In: Hadiyanto (Ed.) Southeast Asian Coal Geology Conference. Ministry of Mines and Energy, Bandung, pp. 239-252.

[25] Palmer, I., Mansoori, J. (1998): How permeability depends on stress and pore pressure in coalbeds: a new model. - SPEREE 1(6):539-544.

[26] Palmer, I.D., Mavor, M., Gunter, B.(2007): Permeability changes in coal seams during production and injection, Intl. - Coalbed Methane Symposium. University of Alabama, Tuscaloosa, Alabama 0713.

[27] Peng W. X., Xue, Q., Ohkoshi, M. (2014): Immune effects of extractives on bamboo biomass self-plasticization. - Pakistan Journal of Pharmaceutical Sciences 27: 991-999.

[28] Qin, Y., Jiang, B., Wang, J. Y., Wu, C. F., Fu, X. H., Wei, Z. T., Hou, Q. L., Ju, Y. W. (2008): Coupling control of tectonic dynamical conditions to coalbed methane reservoir formation in the Qinshui Basin, Shanxi, China. - ActaGeologicaSinica 82(10):1355-1362.

[29] Qin, Y. (2012): Advances and reviews on coalbed methane reservoir formation in china. Geological Journal of China Universities 18(3):405-418.

[30] Shen, Y. L., Qin, Y., Guo, Y. H., Yi, T. S., Yuan, X. X., Shao, Y. B. (2016): Characteristics and sedimentary control of a coalbed methane-bearingsystem in lopingian (late permian) 
coal-bearing strata of westernGuizhouprovince. - Journal of Natural Gas Science and Engineering 33:8-17.

[31] Song, Y., Liu, S. B., Ju, Y. W., Hong, F., Jiang, L., Ma, X. Z., Wei, M. M. (2013): Coupling between gas content and permeability controlling enrichment zones of high abundance coal bed methane. - ActaPetroleiSinica 34(3):417-426.

[32] Su, X. B., Lin, X. Y., Liu, S. B., Zhao, M. J., Song, Y. (2005): Geology of coalbed methane reservoirs in the Southeast Qinshui Basin of China. - International Journal of Coal Geology62:197-210.

[33] Tan, Q. S., Wang, J., Liu, J., Chen, Y. T., Wang, Q. X., Liu, X., Tian, S. S., Chen, Y. Y., Feng, L. (2013): Analysis of main controlling factors for accumulation of coalbed methane in zhengzhuang region. - Journal of Yangtze University (Nat Sci Edit) 10(16): 20-23.

[34] Wang, B., Jiang, B., Wang, H. Y., Chen, Z. H., Liu, H. L., Li, G. Z. (2007): Hydro-geological condition physical simulation of the low rank coalbed methane reservoir formation. - Journal of China Coal Society 32(3):258-260.

[35] Wang, H. M., Zhu, Y. M., Li, W., Zhang, J. S., Luo, Yao. (2011): Two major geological control factors of occurrence characteristics of CBM. - Journal of China Coal Society 36(7):1129-1134.

[36] Wang, H. Y., Lin, G. Z., Li, J. M., Liu, H. L., Wang, B. (2006): Characteristics of CBM enrichment in china. - China Coalbed Methane 3(2):7-10.

[37] Yang, X. C., Liu, Z. D., Chen, C. H., Zhang, J. S., Zhou, K., Li, J. D. (2013): Analysis on influencing factors of CBM enrichment in Hancheng Mining Area. - China Coalbed Methane 10(4):26-32.

[38] Yao, Y. B., Liu, D. M., Yan, T. T. (2014): Geological and hydrogeological controls on the accumulation of coalbed methane in the Weibei field, southeastern Ordos Basin. International Journal of Coal Geology 121:148-159.

[39] Ye, J. P., Wu, Q., Wang, Z. H. (2001): Controlled characteristics of hydrogeological conditionson the coalbed methane migration and accumulation. - Journal of China Coal Society 26(5):459-462.

[40] Ye, J. P., Wu, Q., Ye, G. J., Chen, C. L., Yue, W., Li, H. Z., Zhai, Z. R. (2002): Study on the coalbed methane reservoir-forming dynamic mechanism in the SouthernQinshui Basin, Shanxi. - Geological Review 48(3):319-323.

[41] Zhang, W. J., Li, X. Y. (1998): Analysis of the hydrocarbon-producing potential of main coal measures source rocks in China. - Coal Geology \& Exploration 16(3): 31-37.

[42] Zhou, Q. Q. (2013): Geological control law of coalbed methane accumulation of heshun block in Qinshui Basin. - China Coalbed Methane 10(2):12-15.

[43] Zou, G. G., Peng, S. P., Yin, C. Y., Xu, Y. Y., Chen, F. Y., Liu, J. K. (2013): Seismic studies of coal bed methane content in the west coal mining area of Qinshui Basin. - International Journal of Mining Science and Technology 23:795-803. 